\title{
Studies on alterations of clinical and hemato-biochemical parameters before and after treatment in calves naturally infected with theileriosis
}

\author{
J. P. Kachhawa ${ }^{1}$, Surender Kumar ${ }^{2}$, Ankita Sharma ${ }^{1}$, A. P. Singh ${ }^{1}$ and Anil Ahuja ${ }^{1}$
}

1. Department of Clinical Veterinary Medicine, Ethics and Jurisprudence, College of Veterinary \& Animal Science, Rajasthan University of Veterinary and Animal Sciences, Bikaner - 334 001, Rajasthan, India; 2. Veterinary Hospital, Haripura, Hanumangarh, Rajasthan, India.

Corresponding author: J. P. Kachhawa, e-mail: jpkachhawa@gmail.com, SK: cool.drsurender@rediffmail.com, AS: dr.ankitasharma.vet@gmail.com, APS: drapsinghbikaner@yahoo.co.in, AA: anil ahuja@mail.com

Received: 16-06-2016, Accepted: 05-11-2016, Published online: 07-12-2016

doi: 10.14202/vetworld.2016.1381-1385 How to cite this article: Kachhawa JP, Kumar S, Sharma A, Singh AP, Ahuja A (2016) Studies on alterations of clinical and hemato-biochemical parameters before and after treatment in calves naturally infected with theileriosis, Veterinary World, 9(12): 1381-1385.

\begin{abstract}
Aim: The aim was to determine hemato-biochemical alterations and to determine the better treatment of theileriosis in naturally infected calves.

Materials and Methods: A total of 74 Holstein crossbred calves below 6 months of age, of either sex were included for present investigation in Bikaner. Based on the clinical examinations and laboratory results, 20 calves included for hematobiochemical studies (before and after treatment) and divided into two groups (having 10 calves each).

Results: The clinical examination of these calves revealed weakness, ticks infestations, high fever above $104^{\circ} \mathrm{F}$, pronounced swelling of prescapular, prefemoral, parotid lymph nodes, loss of elasticity of skin, anemia, lacrimal discharges, pulpy cornea, tachycardia, and dyspnea. There was highly significant decrease $(p<0.01)$ in hemoglobin, total erythrocyte count, packed cell volume and total leukocyte count, serum glucose, total protein, globulin and albumin level and highly significant increase in aspartate aminotransferase and alanine aminotransferase level as compared to healthy control animals in Group I and II. The animals of Group II treated with buparvaquone along with single blood transfusion shows better recovery then animals of Group I treated with bupavaqone and hematinic.
\end{abstract}

Conclusions: Significant changes were found in hemato-biochemical parameters in theileria affected calves before treatment as compare to healthy control calves. Significant improvement was observed in hemato-biochemical parameters in buparvaquone and single blood transfusion treated calves as compare to another group, so it is concluded that buparvaquone and single blood transfusion is better combination for treatment of theileriosis.

Keywords: blood transfusion, buparvaquone, calves, hemato-biochemical, theileriosis.

\section{Introduction}

Tropical theileriosis is a major tick-borne protozoan disease of cattle and is associated with high morbidity and mortality. However, indigenous cattle (Boss indicus) are less affected by this disease than crossbred cattle. It is mainly seen in cattle, sheep, and goats as well as in wild and captive ungulates [1-3]. Bovine tropical theileriosis is caused by Theileria annulata is an important disease of cattle in India and is mainly transmitted by tick Hyalomma anatolicum anatolicum.

Theileriosis causes heavy economic losses in terms of high morbidity, mortality and reduced production in recovered animals [4]. Around 10 million cattle are at risk for tropical theileriosis with an annual economic loss of around US \$800 million in India [5].

Copyright: Kachhawa, et al. Open Access. This article is distributed under the terms of the Creative Commons Attribution 4.0 International License (http://creativecommons.org/licenses/ by/4.0/), which permits unrestricted use, distribution, and reproduction in any medium, provided you give appropriate credit to the original author(s) and the source, provide a link to the Creative Commons license, and indicate if changes were made. The Creative Commons Public Domain Dedication waiver (http:// creativecommons.org/publicdomain/zero/1.0/) applies to the data made available in this article, unless otherwise stated.
The mortality rate with $T$. annulata may reach $70 \%$ with case fatality rate of $10-20 \%$ in calves while due to Theileria parva the mortality rate of $100 \%$ has been recorded in exotic cattle [6]. In many epidemiological situations, high mortality occurs only in calves; the adult cattle represent immune survivors [7]. Tentative diagnosis of theileriosis in the field is mainly based on clinical signs and tick infestation on the infected animals. However, confirmation of the diagnosis depends on microscopic examination of Giemsa-stained thin blood smears [8,9]. The demonstration of Koch's blue bodies in the lymphocytes and monocytes of the lymph node smear or peripheral blood film is pathognomonic of the disease [10].

The aim of the present study was to determine hemato-biochemical alterations and to determine the better treatment of theileriosis in naturally infected calves.

\section{Materials and Methods}

\section{Ethical approval}

The study was not conducted on experimental animals. We have taken cases from routine cases reported in clinic, so no need to take ethical approval. 
However, animals were examined and samples were collected as per standard examination and sample collection procedure.

\section{Selection of animals}

For the present investigation, a total of 74 Holstein crossbred calves below 6 months of age, of either sex were included during June to October-2015 belonging to outdoor patients of Teaching Veterinary Clinical Complex, College of Veterinary and Animal Science, Bikaner.

Based on the clinical examinations and laboratory results, 22 calves were diagnosed as positive for theileriosis and divided into two groups, i.e., Groups I and II. Two calves were died from Group I during treatment so excluded from study, rest of 20 calves included for hemato-biochemical studies (before and after treatment) and divided into two groups (having 10 calves each). For comparison of hemato-biochemical status of clinically positive theileriosis infected calves, a total of 10 apparently healthy calves from organized privet dairy farm of Bikaner, were included in this study.

\section{Clinical observations}

Clinical examination included history of ticks infestation, duration of illness, changes in managemental and feeding practice, appetite of the animal, abnormalities in the behavior, gait, posture, rumination, defecation (quantity, consistency and frequency), urination, examination of visible mucous membranes, eyes, skin and anus and general clinical examinations including rectal temperature, pulse, respiration and auscultation of heart and lungs [1].

\section{Hematological studies}

Blood was collected in sterile tubes coated with disodium salt of ethylenediaminetetraacetic acid as an anticoagulant. The blood samples were subjected for determination of hemoglobin $(\mathrm{Hb})$, packed cell volume (PCV), total erythrocyte count (TEC), and total leukocyte count (TLC) of the calves suffering from theileriosis and apparently healthy calves. These parameters were analyzed as per standard methods [11].

\section{Biochemical studies}

For biochemical studies, blood was collected in sterile tubes without anticoagulant on day 0 as pre-treatment and on the $10^{\text {th }}$ day as post-treatment. The blood slants were made and incubated for $1 \mathrm{~h}$ at $37^{\circ} \mathrm{C}$. Blood clots were broken, and tubes were centrifuged at $2500 \mathrm{rpm}$ for $30 \mathrm{~min}$. The serum was pipetted out in small Pyrex tubes and was kept immediately in the deep freeze at $-20^{\circ} \mathrm{C}$ till analysis and was used for estimation of various biochemical parameters like total protein, albumin (Alb), globulin (Glb), glucose, aspartate aminotransferase (AST), and alanine aminotransferase (ALT), using commercially available kits of SPINREACT, S.A. - Ctra. Santa Coloma, 7-E17176 SANT ESTEVE-(Girona), Spain.

\section{Treatment trials}

A total of 20 positive cases of bovine tropical theileriosis infected Holstein crossbred calves were selected for treatment and classified into two groups (Group I and Group II having 10 calves each) irrespective of sex and included for pre- and post-treatment hemato-biochemical studies. Group I was given buparvaquone at the dose rate of $2.5 \mathrm{mg} / \mathrm{kg}$ b.wt. intramuscular. All the cases were given injection oxytetracycline at the dose rate of $10 \mathrm{mg} / \mathrm{kg}$ body weight intramuscular for 5 days and injection analgin at the dose rate of $1.5 \mathrm{~g}$ per calf and supportive treatment with injection B-complex, each ml contains methylcobalamin $500 \mathrm{mcg}$, pyridoxin $50 \mathrm{mg}$, nicotinamide $50 \mathrm{mg}$ were given to each calf intramuscularly as per requirement and hematinic, contains each $21 \mathrm{~g}$ contains: Malt extract - I.P. 4.52, calcium guconate - I.P. $360 \mathrm{mg}$, ferric ammonium citrate - $30 \mathrm{mg}$ (Eq.to $64.5 \mathrm{mg}$ of $\mathrm{Fe}$ ), copper sulfate $-100 \mathrm{mg}$, cobalt chloride $-1.5 \mathrm{mg}$, cholecalciferol - I.P. 3600 IU, nicotinamide - I.P. $45 \mathrm{mg}$, biotin - B.P. $75 \mathrm{mcg}$, folic acid - I.P $1.5 \mathrm{mg}$, cynocobalamin - I.P $15 \mathrm{mcg}$, flaored base q.s., color Caramel I.P. was given at the dose rate of 2 tsf as electuary to all calves.

Calves of Group II were given buparvaquone at the dose rate of $2.5 \mathrm{mg} / \mathrm{kg}$ b.wt. intramuscular. Single blood transfusion in required dose rate was performed in every infected calf. Whole blood was transfused in anemic calves was carried out $[1,12,13]$. While injection analgin at the dose rate of $1.5 \mathrm{~g}$ per calf and supportive treatment with injection B-complex were given to each calf intramuscularly as per requirement.

\section{Statistical analysis}

All statistical data were analyzed using the basic statistics paired Student's t-test by WASP [14], a webbased agricultural statistics software package.

\section{Results and Discussion}

Based on laboratory test results 20 calves were diagnosed as positive for bovine tropical theileriosis from 74 calves during June to October-2015 was studied. The incidence can vary depending on the age of animal, breed, climatic conditions of the region, tick infestations, and management practices.

\section{Clinical manifestations}

All the 22 calves infected with bovine tropical theileriosis were reported to be sick from last few days with additional history of inappetance or total refusal to suckle or feed. The clinical examination of these calves revealed weakness, ticks infestations, high fever above $104^{\circ} \mathrm{F}$, unilateral or bilateral pronounced swelling of prescapular, prefemoral, parotid lymph nodes [1], loss of elasticity of skin, pale or anemic visible mucous membrane $[15,16]$, lacrimal discharges, bilateral exophthalmia with dry and pulpy cornea [17], swelling of knee joints, tachycardia, dyspnea [18], pasty or bloody diarrhea, tachypnea, and dyspnea in few calves $[19,20]$. 
There was highly significant increase $(p<0.01)$ in the mean \pm standard error (SE) value (Table-1) of body temperature, heart rate and respiration rate in bovine tropical theileriosis infected calves in Groups I and II as compared to healthy calves. The suggestive cause is that the cytokines like, tumor necrosis factor- $\alpha$ and interleukins (TNF- $\alpha$, IL-1, and IL-6) produced by infected mononuclear cells are responsible for the diverse clinical symptoms of tropical theileriosis [21,22].

\section{Hematological parameters}

In this study, highly significant $(\mathrm{p}<0.01)$ decrease in mean $\pm \mathrm{SE}$ values of pre-treatment value of $\mathrm{Hb}$, TEC, PCV and TLC level in bovine tropical theileriosis infected calves in Groups I and II as compared to healthy calves (Table-2). Earlier, similar findings were also recorded by several workers [23-25]. Although, some workers also observed significant negative correlations between parasitemia and both red blood cell count and PCV in theileriosis infected cattle [26].

There was highly significant increase $(p<0.01)$ in $\mathrm{Hb}, \mathrm{TEC}, \mathrm{PCV}$ and TLC level as compared to its pre-treatment level in Group I and II. The decline in the values of $\mathrm{Hb}$, TEC, and PCV may be attributed to the destruction of piroplasm infected erythrocytes by macrophages in the lymph nodes, spleen and other organs of the monocyte macrophage system coupled with reduced erythropoietic activity [23,27-29], the toxic effects of metabolites of Theileria species, persistent loss of blood caused by permanent bloodsucking ticks [30] and TNF- $\alpha$ on erythrogenesis [31].

In this study, leukopenia was seen in infected animals could have resulted from large scale destruction of lymphocytes by schizogony in lymphoid organs and infiltration of these cells into various organs, resulting in a decrease count in the peripheral circulation [32-34].

\section{Biochemical parameters}

There was highly significant decrease $(p<0.01)$ in mean \pm SE pre-treatment values of serum total protein, Glb, Alb, glucose and highly significant increase in AST and ALT level in bovine tropical theileriosis infected calves in Groups I and II as compared to healthy calves (Table-3). These findings are in accordance with several workers $[23,26,29,35,36]$. Although, the mean $\pm \mathrm{SE}$ values of serum total protein, Glb, Alb and glucose after treatment in Groups I and II were significantly lower as compared to healthy

Table-1: Mean \pm SE value of clinical parameters in apparently healthy and bovine tropical theileriosis infected calves of Groups I and II (before and after treatment).

\begin{tabular}{|c|c|c|c|c|c|}
\hline \multirow[t]{2}{*}{ Parameters } & \multirow{2}{*}{$\begin{array}{c}\text { Healthy } \\
\text { calves } \\
(n=10)\end{array}$} & \multicolumn{2}{|c|}{ Group I $(n=10)$} & \multicolumn{2}{|c|}{ Group II $(n=10)$} \\
\hline & & Before treatment & After treatment & Before treatment & After treatment \\
\hline $\begin{array}{l}\text { Body } \\
\text { temperature** }\left({ }^{\circ} \mathrm{F}\right)\end{array}$ & $101.56 \pm 0.19^{a}$ & $105.67 \pm 0.16^{b}$ & $101.54 \pm 0.17^{a}$ & $105.84 \pm 0.24^{\mathrm{b}}$ & $101.47 \pm 0.16^{a}$ \\
\hline Heart rate/min** & $107.1 \pm 1.58^{a}$ & $140 \pm 2.91^{b}$ & $112.20 \pm 2.41^{\mathrm{a}}$ & $146.7 \pm 3.08^{b}$ & $111.4 \pm 1.88^{a}$ \\
\hline Respiration rate/min** & $23.6 \pm 0.93^{a}$ & $40.7 \pm 1.66^{b}$ & $26.4 \pm 1.30^{a}$ & $47.4 \pm 1.63^{b}$ & $24.9 \pm 1.00^{\mathrm{a}}$ \\
\hline
\end{tabular}

$* * p<0.01$. Means with different superscripted letters in the same row differ significantly. SE=Standard error

Table-2: Mean \pm SE value of hematological parameters in apparently healthy and bovine tropical theileriosis infected calves of Groups I and II (before and after treatment).

\begin{tabular}{|c|c|c|c|c|c|}
\hline \multirow[t]{2}{*}{ Parameters } & \multirow{2}{*}{$\begin{array}{l}\text { Healthy calves } \\
\qquad(n=10)\end{array}$} & \multicolumn{2}{|c|}{ Group I $(n=10)$} & \multicolumn{2}{|c|}{ Group II $(n=10)$} \\
\hline & & Before treatment & After treatment & Before treatment & After treatment \\
\hline $\mathrm{Hb}(\mathrm{g} / \mathrm{dl})^{* *}$ & $11.67 \pm 0.3^{a}$ & $5.02 \pm 0.27^{b}$ & $5.86 \pm 0.17^{c}$ & $4.39 \pm 0.18^{b}$ & $7.39 \pm 0.20^{c}$ \\
\hline $\operatorname{TEC}\left(10^{12} / \mathrm{L}\right) * *$ & $6.57 \pm 0.30^{a}$ & $3.32 \pm 0.22^{\mathrm{b}}$ & $4.41 \pm 0.27 c$ & $3.49 \pm 0.23^{\mathrm{b}}$ & $5.16 \pm 0.22^{c}$ \\
\hline PCV $(\%)^{* *}$ & $32.98 \pm 0.80^{a}$ & $17.13 \pm 0.74^{b}$ & $22.43 \pm 0.63^{c}$ & $16.80 \pm 0.46^{\mathrm{b}}$ & $25.10 \pm 0.53^{c}$ \\
\hline $\operatorname{TLC}\left(10^{9} / \mathrm{L}\right) * *$ & $6.57 \pm 0.24^{\mathrm{a}}$ & $4.07 \pm 0.12^{\mathrm{b}}$ & $4.67 \pm 0.15^{c}$ & $4.51 \pm 0.16^{\mathrm{b}}$ & $5.74 \pm 0.23^{c}$ \\
\hline
\end{tabular}

$* * \mathrm{p}<0.01$. Means with different superscripted letters in the same row differ significantly. $\mathrm{Hb}=$ Hemoglobin, PCV $=$ Packed cell volume, $\mathrm{TEC}=$ Total erythrocyte count, $\mathrm{TLC}=$ Total leukocyte count, $\mathrm{SE}=$ Standard error

Table-3: Mean \pm SE values of biochemical parameters in apparently healthy and bovine tropical theileriosis infected calves (before and after treatment).

\begin{tabular}{|c|c|c|c|c|c|}
\hline \multirow[t]{2}{*}{ Parameters } & \multirow{2}{*}{$\begin{array}{l}\text { Healthy calves } \\
\qquad(n=10)\end{array}$} & \multicolumn{2}{|c|}{ Group I $(n=10)$} & \multicolumn{2}{|c|}{ Group II $(n=10)$} \\
\hline & & Before treatment & After treatment & Before treatment & After treatment \\
\hline TP $(\mathrm{g} / \mathrm{dl}) * *$ & $6.54 \pm 0.32^{\mathrm{a}}$ & $4.66 \pm 0.17^{b}$ & $5.84 \pm 0.14^{c}$ & $5.04 \pm 0.17^{b}$ & $6.36 \pm 0.22^{c}$ \\
\hline Glb (g/dl)** & $3.64 \pm 0.12^{a}$ & $2.77 \pm 0.14^{b}$ & $3.01 \pm 0.11^{b}$ & $2.97 \pm 0.16^{b}$ & $3.49 \pm 0.49^{c}$ \\
\hline Alb $(g / d l) * *$ & $2.90 \pm 0.22^{\mathrm{a}}$ & $1.88 \pm 0.17^{b}$ & $2.73 \pm 0.11^{c}$ & $2.49 \pm 0.08^{a}$ & $2.92 \pm 0.11^{c}$ \\
\hline Glucose $(\mathrm{mg} / \mathrm{dl}) * *$ & $50.51 \pm 0.92^{a}$ & $33.24 \pm 0.82^{b}$ & $47.14 \pm 1.52^{a}$ & $33.04 \pm 1.49^{b}$ & $47.58 \pm 1.72^{a}$ \\
\hline $\operatorname{ALT}(\mathrm{IU} / \mathrm{L}) * *$ & $27.60 \pm 2.40^{a}$ & $70.37 \pm 6.41^{b}$ & $53.37 \pm 6.54^{c}$ & $81.70 \pm 6.59^{b}$ & $44.33 \pm 4.96^{c}$ \\
\hline $\operatorname{AST}(\mathrm{IU} / \mathrm{L}) * *$ & $44.30 \pm 2.64^{a}$ & $106.44 \pm 6.17^{b}$ & $72.04 \pm 6.69^{c}$ & $121.76 \pm 6.58^{b}$ & $84.65 \pm 6.39^{c}$ \\
\hline
\end{tabular}

$* * p<0.01$. Means with different superscripted letters in the same row differ significantly. Alb=Albumin, Glb=Globulin, AST=Aspartate aminotransferase, ALT=Alanine aminotransferase, TP=Total protein 
control. The decreased glucose serum concentration may be due to the abnormalities in liver functions and/or abnormalities in metabolism and anorexic state of affected animals [34,37,38]. The decreased serum total protein concentration, hypoalbuminemia and hyperglobulinemia could be explained that in naturally infected cattle with $T$. annulata causes liver failure [35,39]. Moreover, extra-vascular proteinaceous fluid in body cavities due to diseased lymph nodes $[36,40]$, anorexia and diarrhea also cause hypoproteinemia $[23,41]$. There was highly significant decrease after treatment were observed in serum ALT and AST level in Groups I and II as compared to its pre-treatment level in all diseased groups.

Serum AST and ALT concentrations are the indicators of hepatic function [21] and are involved in amino acid and carbohydrade metabolism. T. annulata infection cause hepatic tissue damage that includes coagulative necrosis, distortion of hepatic cords and heavy infiltration of lymphocytes in the periportal areas [34].

\section{Group-wise comparison of treatment trial}

Comparative efficacy of treatment in Groups I and II was seen with regard to clinical, hematological and biochemical parameters before and after treatment.

Out of 12 cases in Group I, two calves died during treatment. Seven cases received only single dose of injection buparvaquone. However, buparvaquone was repeated $48 \mathrm{~h}$ after first dosing in 3 calves. While no mortality observed in Group II. In the present investigation, the cure rates of Group I (buparvaquone and hematinics) and Group II (buparvaquone and single blood transfusion) were $83.33 \%$ and $100 \%$, respectively.

Buparvaquone is a second generation hydroxynaphthoquinone which inhibits the electron transport chain system of protozoa and not that of the host $[42,43]$. Several clinician successfully used buparvaquone as a drug of choice for the treatment of theileriosis in cattle alone $[44,45]$ or in combination of oxytetracycline $[16,46]$.

\section{Conclusion}

The altered mean \pm SE values of hemato-biochemical parameters after treatment in Group I and II were near to the healthy control. However, the value attained in Group II was nearer to the healthy control with respect to other groups, indicated better recovery so buparvaquone and single blood transfusion is better combination for treatment of theileriosis.

\section{Authors' Contributions}

JPK and SK designed and planned the study. JPK and AS collected the samples and prepared the onsite smears slides. JPK, APS, and AS performed clinical, hemato-biochemical and treatment part of the study. APS and AA drafted the manuscript. All authors read and approved the final manuscript. JPK finalized the manuscript and sent for publication.

\section{Acknowledgments}

The authors acknowledged Dr. Anil Ahuja, Professor and Head, Department of Clinical Veterinary Medicine, Ethics and Jurisprudence, College of Veterinary and Animal Science, RAJUVAS, Bikaner for his valuable help in conduct of this study. Funds and facilities of department were utilized for conducting present study.

\section{Competing Interests}

The authors declare that they have no competing interests.

\section{References}

1. Radostits, O.M., Gay, C.C., Hinchcliff, K.W. and Constable, P.D. (2007) Veterinary Medicine. $10^{\text {th }}$ ed. W. B. Saunders Company Ltd., Philadelphia, PA.

2. Dewangan, P., Panigrahi, M., Kumar, A., Saravanan, B.C., Ghosh, S., Asaf, V.N., Parida, S., Gaur, G.K., Sharma, D. and Bhushan, B. (2015) The mRNA expression of immune-related genes in crossbred and Tharparkar cattle in response to in vitro infection with Theileria annulata. Mol. Biol. Rep., 42(8): 1247-1255.

3. Morrison, W.I. (2015) The aetiology, pathogenesis and control of theileriosis in domestic animals. Rev. Sci. Tech., 34(2): 599-611.

4. Haque, M., Jyoti, Singh, N.K. and Rath, S.S. (2010) Prevalence of Theileria annulata infection in Hyalomma anatolicum anatolicum in Punjab state, India. J. Parasitol. Dis., 34(1): 48-51.

5. Devendra, C. (1995) In: Global Agenda for Livestock Research. EDS, ILRI, Nairobi. p41-48.

6. Moorhouse, P.D.S., Musisi, F.L., Mwase, E.T. and Snacken, M. (2001) The epidemiology of bovine theileriosis in Zambia: Results of a longitudinal study in Southern Province. In: Proceedings of the $4^{\text {th }}$ International Symposium on Veterinary Epidemiology and Economics. Singapore Veterinary Association, Singapore. p389-391.

7. Tahir, M. (2000) Vaccine against B. microplus and evaluate the comparative efficacy of vaccines prepared from midgut, salivary gland and whole tick in terms of antibody titers and percentage of tick rejection. Report of Pilot Project. Livestock Experiment Station Qadirabad, Sahiwal, Pakistan.

8. Aktas, M., Altay, K. and Dumanli, N. (2006) A molecular survey of bovine Theileria parasites among apparently healthy cattle and with a note on the distribution of ticks in eastern Turkey. Vet. Parasitol., 138: 179-185.

9. OIE. (2008) Manual of Diagnotic Tests and Vaccines for Terrestrial Animals. $6^{\text {th }}$ ed. Office International des Epizooties, Paris.

10. Tayo, T., Longjam, N. and Perme, B. (2011) Protozoan diseases of livestock in Arunachal Pradesh - An overview. Vet. World, 4(7): 332-336.

11. Jain, N.C. (1986) Schalm's Veterinary Haematology. $4^{\text {th }}$ ed. Lea and Febiger, Philadelphia, PA.

12. Alam, M.R. and Hossain, M.A. (2005) Effects of repeated plasma transfusion on various hematological parameters in calves. Pak. J. Biol. Sci., 8(9): 1280-1283.

13. Singh, D.V., Singh, R. and Singh, S.P.S. (2005) Effect of blood transfusion in combination with dextran-40 and hypertonic saline solution on cardiopulmonary haemodynamics of endotoxin (Lipopolysaccharide) shock in buffalo calves. Vet. Res. Commun., 29: 421-430.

14. WASP. (2015) Web Agri Stat Package 2. Available from: http://www.icargoa.res.in/wasp2.0/index.php. Accessed on 19-11-2015.

15. Branco, S., Orvalho, J., Leitao, A., Pereira, I., Malta, M., Carvalho, T., Baptista, R., Shiels, B.R., Peleteiro, M.C. and 
Mariano, I. (2010) Fatal cases of Theileria annulata infection in calves in Portugal associated with neoplastic-like lymphoid cell proliferation. J. Vet. Sci., 11(1): 27-34.

16. Kohli, S., Atheya, U.K., Srivastava, S.K., Banerjee, P.S. and Garg, R. (2014) Outbreak of theileriosis and anaplasmosis in herd of Holstein crossbred cows of Dehradun district of Uttranchal, India: A Himalyan region. Int. J. Livest. Prod., 5(1): 182-185.

17. Singh, S.K., Sudan, V., Sachan, P. and Srivastava, A. (2015) Salvage of Theileria infected calves with clinical manifestation of exophthalmia. J. Parasitol. Dis., 39(3): 448-451.

18. Bhojne, G.R., Dakshinkar, N.P., Dhoot, V.M., Kolte, S.W. and Gupta, D. (2010) Herd outbreak and management of bovine theileriosis. Intas Polivet, 11(1): 21-22.

19. Issi, M., Gul, Y. and Basbug, O. (2011) The effect of classical theileriosis treatment on thyroid hormone levels in cattle naturally infected with Theileria annulata. Asian J. Anim. Vet. Adv., 6(5): 531-536.

20. Vahora, S.P., Patel, J.V., Patel, B.B., Patel, S.B. and Umale, R.H. (2012) Seasonal incidence of haemoprotozoal diseases in crossbred cattle and buffalo in Kaira and Anand districts of Gujarat, India. Vet. World, 5(4): 223-225.

21. Forsyth, L.M.G., Minns, F.C., Kirvar, E., Adamson, R.E., Hall, F.R., McOrist, S., Brown, C.G.D. and Preston, P.M. (1999) Tissue damage in cattle infected with Theileria annulata accompanied by metastasis of cytokine-producing, schizont-infected mononuclear phagocytes. J. Comp. Pathol., 120: 39-57.

22. Glass, E.J., Craigmile, S.C., Springbett, A., Preston, P.M. and Brown, C.G.D. (2003) The protozoan parasite, Theileria annulata, induces a distinct acute phase protein response in cattle that is associated with pathology. Int. J. Parasitol., 33: 1409-1418.

23. Singh, A., Singh, J., Grewal, A.S. and Brar, R.S. (2001) Studies on some blood parameters of crossbred calves with experimental Theileria annulata infections. Vet. Res. Commun., 25: 289-300.

24. Mahmmod, Y.S., Elbalkemy, F.A., Klaas, I.C., Elmekkawy, M.F. and Monazie, A.M. (2011) Clinical and haematological study on water buffaloes (Bubalus bubalis) and crossbred cattle naturally infected with Theileria annulata in Sharkia province, Egypt. Tick Borne Dis., 2(3): 168-171.

25. Razavi, S.M., Nazifi, S., Rakhshandehroo, E., Firoozi, P. and Farsandaj, M. (2012) Erythrocyte antioxidant systems, lipid peroxidation and circulating lipid profiles in cattle naturally infected with Theileria annulata. Rev. Med. Vet., 163(1): 18-24.

26. Fartashvand, M., Nadalian, M.G., Sakha, M. and Safi, S. (2013) Elevated serum cardiac Troponin I in cattle with theileriosis. J. Vet. Intern. Med., 27: 194-199.

27. Soulsby, E.J.L. (1982) Helminths, Arthropods and Protozoa of Domesticated Animals. $7^{\text {th }}$ ed. Baillier Tindall and Cassel Ltd., London.

28. Campbell, J.D.M. and Spooner, R.L. (1999) Macrophages behaving badly infected cells and subversion of immune responses to Theileria annulata. Parasitol. Today, 15: 10-16.

29. Ugalmugle, S.S., Jayraw, A.K. and Gatne, M.L. (2010) Prevalence and clinical pathology of bovine tropical theileriosis in cross-bred population of Ahmednagar district of Maharashtra. J. Vet. Parasitol., 24(2): 141-145.

30. Geerts, S.P., Holmes, H., Diall, O. and Eisler, M.C. (2001) African bovine theileriosis: The problem of drug resistance. Trends Parasitol., 17: 25-28.

31. Boulter, N. and Hall, R. (2000) Immunity and vaccine development in the bovine theileriosis. Adv. Parasitol., 44: 41-97.

32. Al-Kushali, M.N., Al-Dahash, S.Y., Mahmoud, G.S. and Joshi, B.P. (1981) Study for haematological parameters in clinical theileiosis in Iraqi cattle. Indian Vet. J., 7: 70-72.

33. Mehta, H.K., Sisodia, R.S. and Misraulia, K.S. (1988) Clinical and haematological observation in experimentally induced cases of bovine tropical theileriosis. Indian $J$. Anim. Sci., 58: 584-587.

34. Sandhu, G.S., Grewal, A.S., Singh, A., Kondal, J.K., Singh, J. and Brar, R.S. (1998) Haematological and biochemical studies on experimental Theileria annulata infection in crossbred calves. Vet. Res. Commun., 22: 347-354.

35. Yurtseven, S. and Uysal, H. (2009) Decreased serum sialic acid, albumin-globulin ratio and total protein levels in cattle heavily infected with Theileria annulata. Ankara Univ. Vet. Fak., 56: 141-144.

36. Khan, I.A., Khan, A., Hussain, A., Riaz, A. and Aziz, A. (2011) Hemato-biochemical alterations in cross bred cattle affected with bovine theileriosis in semi arid zone. Pak. Vet. J., 31(2): 137-140.

37. Hussein, A.H., Mohammed, N.A.E. and Mohammed, H.K. (2007) Theileriosis and Babesiosis in cattle: Haemogram and some biochemical parameters. ISAH-2007 Tartu, Estonia. p143-150.

38. El-Deeb, W.M. and Younis, E.E. (2009) Clinical and biochemical studies on Theileria annulata in Egyptian buffaloes (Bubalus bubalis) with particular orientation to oxidative stress and ketosis relationship. Vet. Parasitol., 164: 301-305.

39. Omer, O.H., Ei-Malik, K.H., Magzoub, M., Mohmoud, O.M., Haroun, E.M., Hawas, A. and Omar, H.M. (2003) Biochemical profiles in Friesian cattle naturally infected with Theileria annulata in Saudi Arabia. Vet. Res. Commun., 27: 15-25.

40. Stockham, S., Kjemtrup, A., Conrad, P., Schmit, D., Scott, M., Robinson, T., Tyler, J., Jonson, G., Carson, C. and Cuddihee, P. (2000) Theileriosis in a Missouri beef herd caused by Theileria buffeli: Case report, herd investigation, ultrastructure, phylogenetic analysis, and experimental transmission. Vet. Pathol., 37: 11-21.

41. Singh, A. (1998) Clinicopathological studies on experimental Theileria annulata infection in crossbred calves. M.V.Sc. Thesis, Subimitted to Punjab Agricultural University, Ludhiana.

42. McColm, A.A. and McHardy, N. (1984) Evaluation of a range of antimicrobial agents against the parasitic protozoa, Plasmodium falciparum, Babesia rodhaini and Theileria parva in vitro. Ann. Trop. Med. Parasitol., 78(4): 345-354.

43. Hudson, A.T., Randall, A.W., Fry, M., Ginger, C.D., Hill, B., Latter, V.S., McHardy, N. and Williams, R.B. (1985) Novel antimalarial hydroxynaphthoquinones with potent broad-spectrum anti-protozoal activity. Parasitology, 90: 45-55.

44. Masare, P.S., Bhikane, A.U., Syed, A.M., Ghoke, S.S. and Awaz, K.B. (2009) Epidemiological and clinico-therapeutic studies on theileriosis in calves. Intas Polivet, 10(2): 289-292.

45. Naik, G., Ananda, K.J. and Rani, B.K. (2010) Theileriosis in calves and its successful treatment. Vet. World, 3(4): 191.

46. Bhatt, P., Kumar, S., Sharma, G. and Shukla, S.K. (2012) Management of concurrent amphistomosis and theileriosis in a cross bred cattle. Vet. Pract., 13(1): 109-110. 